Beyond Liberal Democracy 
This page intentionally left blank 


\title{
BEYOND LIBERAL DEMOCRACY
}

\author{
Political Thinking \\ for an East Asian Context
}

Daniel A. Bell

PRINCETON UNIVERSITY PRESS PRINCETON AND OXFORD 
Copyright (C 2006 by Princeton University Press

Requests for permission to reproduce material from this work should be sent to Permissions, Princeton University Press

Published by Princeton University Press, 41 William Street, Princeton, New Jersey 08540 In the United Kingdom: Princeton University Press, 3 Market Place, Woodstock, Oxfordshire OX20 1SY

All Rights Reserved

Library of Congress Cataloging-in-Publication Data

Bell, Daniel (Daniel A.)

Beyond liberal democracy : political thinking for an East Asian context /

Daniel A. Bell.

p. $\mathrm{cm}$.

ISBN-13: 978-0-691-12307-3 (alk. paper)

ISBN-10: 0-691-12307-1 (alk. paper)

ISBN-13: 978-0-691-12308-0 (pbk. : alk. paper)

ISBN-10: 0-691-12308-X (pbk. : alk. paper)

1. Democracy-East Asia. 2. Human rights-East Asia. 3. Capitalism-

East Asia. 4. East Asia-Politics and government. I. Title.

JQ1499.A91B45 2006

321.8095-dc22 2006002730

British Library Cataloging-in-Publication Data is available

This book has been composed in Sabon

Printed on acid-free paper. $\infty$

pup.princeton.edu

Printed in the United States of America 
In memory of Don Bell

Father and writer 
This page intentionally left blank 